\title{
VBAC: Access to Care and Autonomy in the North Country of New York Demands Persistence
}

\author{
Sarah Oakley ${ }^{1}$
}

Autonomy in birth is key to achieving healthy outcomes for mothers and babies. For birthing people in the North Country, there is a gap between what evidence-based ethical care looks like in theory and access to that care in reality. VBAC (Vaginal Birth After Cesarean) bans, or de facto bans, fall within this gap and leave birthing people without choice and autonomy over their bodies. When barriers such as VBAC bans are in place, people in rural areas do not have a choice as to how they birth and are forced into surgical birth. There are risks and benefits with VBAC and with repeat cesarean. The WHO (World Health Association), NIH (National Institutes of Health) \& ACOG (American College of Obstetricians and Gynecologist) provide evidence-based recommendations for VBAC. It is a birthing person's right to be presented with all the information and to be given the opportunity to make informed consent or informed refusal. This paper provides insight into lack of access to VBAC in the North Country of New York, specifically St. Lawrence County, and examines why this is an important community health issue that demands persistence. [Article copies available for a fee from The Transformative Studies Institute. E-mail address: journal@transformativestudies.org Website: http://www.transformativestudies.org (C2019 by The Transformative Studies Institute. All rights reserved.]

KEYWORDS: VBAC, Cesarean, Pregnancy, Birth.

\footnotetext{
${ }^{1}$ Sarah Oakley is a Certified Prenatal and Postnatal Yoga Teacher, Certified Prison Yoga Project Teacher, a Certified Lamaze Childbirth Educator, and Certifying Birth and Postpartum Doula. She is a founding member of St. Lawrence County Birth Connection, served for three years as a chapter leader for ICAN of Syracuse, and was a founding member of Birth Network CNY. She has attended continuing education training workshops with: Cristen Pascucci of Birth Monopoly - Stand on Your Rights: Demystifying Legal Rights in Childbirth \& How to Use Them, 'The Truth about VBAC" with Jennifer Kamel of VBAC Facts, Breastfeeding Workshop for Birth Professionals with Jen Deshaies of Syracuse Lactation, and Crouse Hospital Perinatal Mood Disorders Training. She has been a guest presenter for Doula Trainings International, Crouse Hospital Labor and Delivery Nursing Students, Crouse Hospital Childbirth Education Classes, and Lotus Life Yoga Center Teacher Trainings. Prior to birth work, she also completed a Bachelor of Science from Indiana University in Outdoor Recreation and Resource Management.
} 